\title{
LAJU TANGKAP UNIT PUKAT PANTAI DI KABUPATEN PANGANDARAN
}

\author{
Beach Seine Catch Rate in Pangandaran
}

\author{
Oleh: \\ Izza Mahdiana Apriliani ${ }^{1}$, Isni Nurruhwati ${ }^{1}$, Achmad Rizal ${ }^{1}$ \\ ${ }^{1}$ Departemen Perikanan, Fakultas Perikanan dan Ilmu Kelautan Universitas Padjadjaran \\ Korespondensi:izza.mahdiana@unpad.ac.id
}

\begin{abstract}
ABSTRAK
Penelitian ini bertujuan untuk mengkaji laju tangkap dan hasil tangkapan pada perikanan pukat pantai di Kabupaten Pangandaran. Pangandaran merupakan salah satu daerah yang masih mengoperasikan unit penangkapan pukat pantai. Data yang dikumpulkan meliputi hasil tangkapan, upaya penangkapan serta waktu penangkapan dari unit perikanan pukat pantai. Data dianalisis secara kuantitatif yang menggambarkan komposisi hasil tangkapan dan nilai laju tangkap. Penelitian dilaksanakan pada bulan Februari dan Maret 2017 di Kabupaten Pangandaran yang masih terdapat operasi penangkapan ikan dengan pukat pantai. Hasil penelitian menunjukkan bahwa dalam operasi penangkapan pukat pantai memiliki target tangkapan diantaranya, ikan teri (Stolephorus sp.), ikan layur (Trichiurus sp.) dan ikan pepetek (Leiognathus sp.) dalam 2 (dua) musim penangkapannya. Pengoperasian pukat pantai dengan hasil tangkapan ikan teri memiliki nilai laju tangkap sebesar 0,7 $\mathrm{kg} / \mathrm{jam}$. Nilai laju tangkap dari pengoperasian pukat pantai sebesar $24,25 \mathrm{~kg} / \mathrm{hari}$. Perikanan pukat pantai memiliki nilai catch rate hasil tangkapan sampingan yang lebih besar dibandingkan nilai catch rate target tangkapannya.
\end{abstract}

Kata kunci: hasil tangkapan, laju tangkap, Pangandaran, pukat pantai

\begin{abstract}
This study aims to examine the catch rate and catch of beach seine in Pangandaran Regency. Pangandaran is one area that still operates a beach seine unit. Data collected includes catches, effort and time of capture from the beach seine. Data were analyzed quantitatively which illustrates the composition of the catch and catch rate. The study was conducted in February and March 2017 in Pangandaran Regency where there are still fishing operations using beach seine. The results showed that the fishing operations of beach seine had catch targets including anchovy (Stolephorus sp.), hair tail (Trichiurus sp.) and ponyfish (Leiognathus sp.) in 2 (two) fishing seasons. The operation of beach seine with anchovy catches has a catch rate of $0,7 \mathrm{~kg} / \mathrm{hour}$. The catch rate from beach seine operations is $24,25 \mathrm{~kg} /$ day. Beach seine have a bycatch greater than the target catch.
\end{abstract}

Key words: beach seine, catch, catch rate, Pangandaran

\section{PENDAHULUAN}

Perairan Pangandaran merupakan kawasan yang memiliki potensi dalam bidang pariwisata maupun perikanan tangkap. Potensi tersebut memberikan peluang bagi masyarakat dalam peningkatan kesejahteraan ekonomi bagi masyarakat dan pendapatan daerah Kabupaten Pangandaran. Nilai potensi lestari perikanan tangkap di kawasan Pangandaran mencapai 1.567 ton pada tahun 2013 (Nurhayati, 2013). Potensi tersebut besar dipengaruhi oleh letak geografis yang strategis serta sarana prasarana aktivitas perikanan tangkap yang menunjang di kabupaten ini. 
Pangandaran merupakan salah satu daerah yang masih mengoperasikan unit penangkapan pukat pantai. Alat tangkap ini masih dipertahankan di Pangandaran karena memiliki sifat gotong royong antar warga dengan melibatkan setidaknya 6 sampai 30 orang dalam proses operasi. Tingginya aktivitas penangkapan pukat pantai ini kemudian memiliki wilayah khusus dalam proses pengoperasiannya di wilayah Pangandaran.

Target utama dalam aktivitas penangkapan pukat pantai di Pangandaran adalah komoditas ikan teri. Oleh karena itu penggunaan waring pada bagian kantong memiliki mesh size yang relatif kecil. Hal tersebut kaitannya dengan berbagai jenis hasil tangkapan yang dapat tertangkap tertangkap selama proses operasi penangkapan berlangsung. Eksploitasi penangkapan yang meningkat dapat menyebabkan sumberdaya ikan mengalami tekanan penangkapan diakibat proses penangkapan. Penurunan produksi dapat terjadi karena tidak adanya pembatasan akses seperti pembatasan konstruksi unit penangkapan, kapasitas dan kelebihan penangkapan (Setiawan et al., 2010). Keberlanjutan usaha perikanan tangkap dapat ditentukan dari besarnya produksi dan keuntungan usaha yang dapat diperoleh, dimana produksi dan keuntungan dipengaruhi oleh laju tangkap (Boesono et al., 2011)

Penelitian ini fokus kepada hasil tangkapan yang diperoleh dari operasi penangkapan dengan alat tangkap pukat pantai. Hasil tangkapan selanjutnya dikelompokkan berdasarkan komposisi jenis dan jumlahnya serta dianalis laju tangkap (catch rate). Hal tersebut bertujuan untuk menggambarkan kemampuan suatu unit penangkapan pukat pantai dalam menghasilkan tangkapan per satuan waktu. Tujuan dari penelitian ini untuk mengetahui komposisi hasil tangkapan (jumlah dan jenis) dan menganalisis laju tangkap per satuan waktu dari pukat pantai yang terdapat di wilayah Pangandaran. Manfaat dari penelitian ini adalah basis data dalam pengelolaan perikanan pukat pantai, khususnya dalam pengelolaan sumberdaya perikanan tangkap di Pangandaran.

\section{METODE PENELITIAN}

Penelitian dilaksanakan bulan Februari sampai Maret 2017. Alat yang digunakan dalam penelitian ini adalah kuisioner yang digunakan dalam proses wawancara dengan nelayan, timbangan, penggaris dan alat tulis. Bahan yang digunakan yaitu ikan hasil tangkapan yang diperoleh selama trip. Obyek penelitian adalah kegiatan operasi penangkapan dengan pukat pantai di Pangandaran.

Metode penelitian ini yaitu metode studi kasus. Kasus yang menjadikan dasar dari penelitian ini adalah penggunaan alat tangkap pukat pantai yang masih dipertahankan di Pangandaran. Pengumpulan data dilakukan dengan menggunakan metode survei dan wawancara serta studi literatur. Kegiatan survei lapangan dilakukan bersama dengan nelayan (mengikuti) melakukan operasi penangkapan ikan. Data yang dibutuhkan dalam penelitian ini adalah hasil tangkapan (jenis, $\mathrm{kg} / \mathrm{trip}$, ekor/trip) dan periode trip. Data yang diperoleh selanjutnya dianalisis secara deskriptif, dengan cara klasifikasi, tabulasi, dan interpretasi data serta disajikan dalam bentuk tabel dan grafik. Analisis laju tangkap menggunakan interpretasi formulasi Shindo (Sparre \& Venema, 1999) sebagai berikut:

$$
\text { Laju tangkap, } c r=\frac{\text { catch }}{\text { effort }}
$$

dengan:

cr $\quad=$ laju tangkap $(\mathrm{kg} / \mathrm{jam})$

catch = hasil tangkapan $(\mathrm{kg})$

effort = upaya penangkapan (dikonversi dari per towing/hauling/trip dalam satuan jam)

\section{HASIL DAN PEMBAHASAN}

Penggunaan unit penangkapan pukat pantai di Pangandaran memiliki konstruksi yang dimodifikasi dengan jenis bahan dan ukuran yang berbeda. Armada yang membantu proses pengoperasian dengan menggunakan kapal jenis perahu. Bahan penyusun perahu terbuat dari 
kombinasi kayu dan fiber glass. Awak kapal berjumlah dua sampai empat orang yang bertugas dalam proses setting alat di laut. Alat tangkap pukat pantai ini merupakan salah satu kearifan lokal sehingga pada proses hauling melibatkan 8 sampai 12 orang salam satu unit alat tangkap (Apriliani et al., 2017).

Daerah penangkapan dilakukan di sekitar pantai Pangandaran. Penentuan daerah penangkapan masih bergantung pada naluri nelayan, sehingga belum didukung oleh peralatan modern. Waktu operasi dilakukan pada pagi sampai siang hari selama 6 jam. Berdasarkan Firdaus (2010) pukat tarik memiliki kecenderungan pengoperasian pada saat pasang rendah, hal ini dikarenakan kondisi perairan mengindikasikan pengoperasian yang tidak membahayakan nelayan dan memudahkan dalam proses towing (penarikan).

Berdasarkan hasil di lapangan menyebutkan bahwa target hasil tangkapan yang diharapkan oleh nelayan adalah ikan teri (Stolephorus sp.). Namun berdasarkan hasil tangkapan dari operasi penangkapan yang dilakukan selama 10 kali trip dihasilkan beberapa jenis ikan ekonomis diantaranya ikan teri (Stolephorus sp.), ikan layur (Trichiurus sp.), cumi-cumi (Loligo sp.), ikan pepetek (Leiognathus sp.), ikan tenggiri (Scomberomorus sp.), ikan layang (Decapterus sp.), dan ikan bawal putih (Pampus sp.). Selain itu, terdapat pula ikan non ekonomis (discard) yaitu ikan sebelah, ikan buntal, kuda laut dan terdapat juga beberapa sampah plastik.

Target utama hasil tangkapan pukat pantai di Pangandaran yaitu hanyalah ikan teri, hal ini terlihat dari konstruksi alat tangkap bagian kantong menggunakan waring dengan mesh size hanya 0,5 $\mathrm{cm}$ yang berfungsi untuk menangkap ikan teri. Terdapat beberapa ikan yang ekonomis penting yang tertangkap namun tidak dijadikan target utama dikarenakan ikan layur, cumi, layang, bawal maupun tenggiri tidak kontinyu tertangkap oleh pukat pantai. Komposisi hasil tangkapan disajikan dalam Tabel 1.

Tabel 1 Komposisi hasil tangkapan pada pukat pantai selama penelitian

\begin{tabular}{cccccccccc}
\hline \multirow{2}{*}{ Trip } & \multicolumn{7}{c}{ Komposisi Hasil Tangkapan $(\mathrm{kg})$} & \\
\cline { 2 - 7 } & Teri & Layur & Cumi & $\begin{array}{c}\text { Pepete } \\
\mathrm{k}\end{array}$ & Layang & $\begin{array}{c}\text { Bawal } \\
\text { Putih }\end{array}$ & $\begin{array}{c}\text { Tenggi } \\
\text { ri }\end{array}$ & $\begin{array}{c}\text { Discar } \\
d\end{array}$ & Jumlah \\
\hline 1 & 3,6 & 1,5 & 0,5 & 3,2 & 2,2 & 0,9 & 0,6 & 2,5 & 15 \\
2 & 3,5 & 8 & 5,6 & 8,9 & 0 & 0 & 4 & 5,5 & 35,5 \\
3 & 5,6 & 2 & 1,5 & 2,7 & 2,2 & 1,7 & 1 & 2,3 & 19 \\
4 & 3,2 & 5,7 & 0 & 0 & 5,8 & 0 & 3,6 & 5,2 & 23,5 \\
5 & 4,8 & 2,9 & 0 & 5 & 4 & 0 & 2,5 & 2,8 & 22 \\
6 & 5,6 & 4,8 & 3,1 & 7,1 & 6,2 & 0 & 0 & 4,8 & 31,6 \\
7 & 5 & 0 & 3,2 & 4,5 & 0 & 1,8 & 1,5 & 2 & 18 \\
8 & 3,5 & 4,8 & 3 & 5,2 & 0 & 1,5 & 0 & 4,5 & 22,5 \\
9 & 2,6 & 5,2 & 0 & 6 & 3,7 & 0 & 3 & 4 & 24,5 \\
10 & 4,5 & 3,5 & 4,5 & 5,2 & 4,6 & 2 & 3 & 3,5 & 30,8 \\
\hline Jumlah & 41,9 & 38,4 & 21,4 & 47,8 & 28,7 & 7,9 & 19,2 & 37,1 & 242,4 \\
\hline
\end{tabular}

Hasil tangkapan perikanan pukat pantai dengan target tangkapan utama ikan teri, menghasilkan tangkapan sebanyak $41,9 \mathrm{~kg}$ selama penelitian. Banyaknya teri yang dihasilkan lebih sedikit dibandingkan ikan pepetek yang dihasilkan sebesar 47,8 kg. Hal ini dikarenakan wilayah perairan Pangandaran terdapat muara sungai, dan salah satu habitat yang dihuni oleh ikan pepetek diantaranya wilayah muara sungai (Blaber, 1997). Ikan petek merupakan ikan demersal yang paling banyak tertangkap di perairan Laut Jawa yaitu sebesar 60\% (Sumiono et al., 2002). 
Jenis ikan pelagis yang banyak tertangkap selama operasi penangkapan menggunakan pukat pantai ini yaitu ikan layur dan layang masing-masing sebesar 38,4 kg dan 28,7 kg. Kemungkinan tertangkapnya ikan ini karena sifatnya bergerombol sehingga mudah tertangkap. Ikan pelagis lain yang tertangkap yaitu ikan tenggiri sebesar 19,2 kg, tertangkapnya ikan tenggiri kemungkinan karena mencari mangsa di pagi dan siang hari sehingga tertangkap oleh alat tangkap ini. Berdasarkan Jumsurizal et al. (2014) produktivitas penangkapan ikan tenggiri lebih tinggi di pagi sampai siang hari karena tingkah laku makan ikan tenggiri yang lebih rakus di pagi dan siang hari. Cumi-cumi yang tertangkap oleh pukat pantai selama penelitian didapatkan sebesar 21,4 kg. Jumlah tersebut cukup besar, dikarenakan karakteristik perairan jawa merupakan habitat dari cumi-cumi (Triharyuni et al., 2012). Hasil tangkapan lainnya yang dinyatakan discard memperoleh sebanyak $37,1 \mathrm{~kg}$ yang didominasi oleh sampah plastik. Banyaknya sampah plastik di perairan pangandaran juga dikarenakan wilayah ini dekat dengan muara sungai sehingga memiliki dampak limbah rumah tangga yang masuk ke wilayah perairan ini.

Laju tangkap merupakan kemampuan tangkap suatu alat tangkap per upaya penangkapan (Firdaus, 2010). Hasil tangkapan dalam satuan gram/kilogram mewakili kemampuan tangkap suatu alat tangkap. Upaya penangkapan yang menjadi bagian dalam analisis laju tangkap yaitu lama pemasangan, lama penarikan (lama rendaman/terapung) sampai durasi pengangkatan yang dikonversi dalam satuan waktu (jam/hari). Berdasarkan hasil penelitian dan analisis data terhadap alat tangkap pukat pantai di Pangandaran, terdapat perbedaan laju tangkap berdasarkan hasil tangkapan. Grafik hasil tangkapan pukat pantai dibandingkan dengan laju tangkap, dapat dilihat pada Gambar 1.

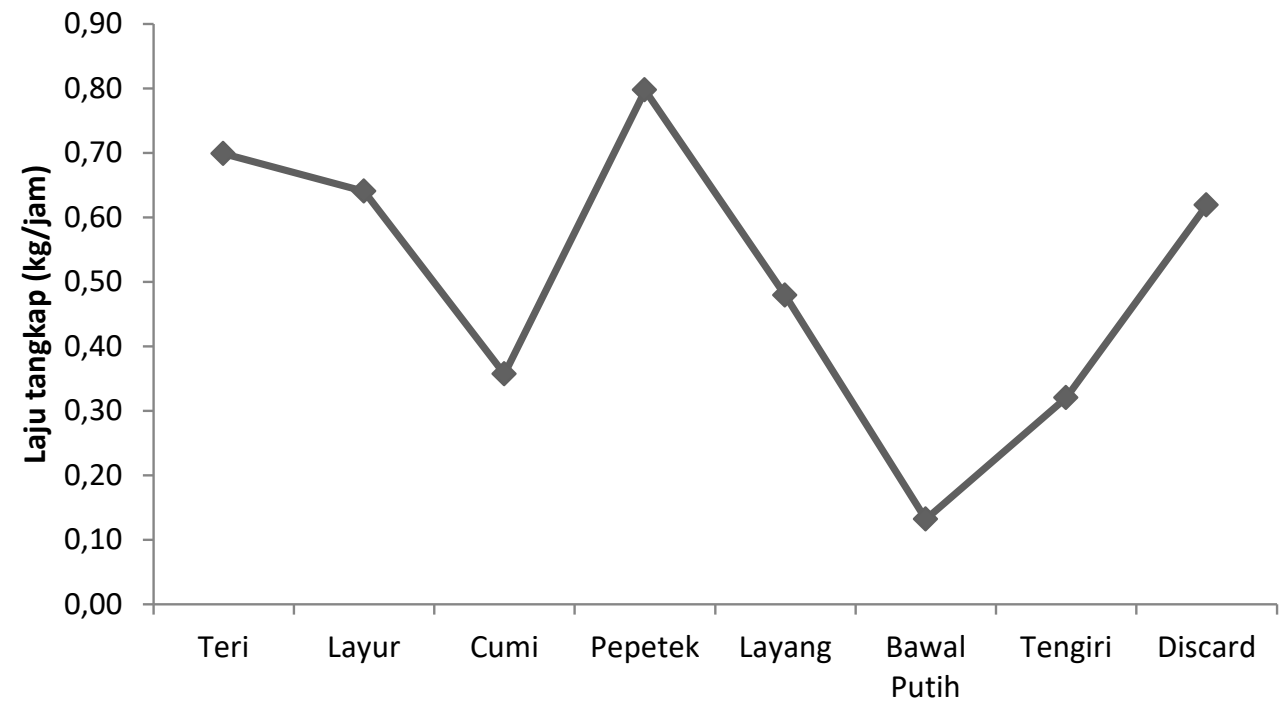

Jenis hasil tangkapan

Gambar 1 Laju tangkap pukat pantai terhadap jenis hasil tangkapan

Nilai laju tangkap dari pengoperasian pukat pantai di Pangandaran sebesar 24,25 kg/hari. Nilai tersebut termasuk sedikit, berdasarkan hasil lapangan menunjukkan bahwa laju tangkap pukat pantai mampu mencapai 1 ton/hari. Hasil tangkapan yang menurun mungkin disebabkan jumlah armada yang beroperasi pada musim peralihan (Maret-Mei dan September-Nopember) cenderung tinggi dibandingkan pada saat musim barat maupun timur, hal ini dikarenakan pada musim peralihan armada lebih sering beroperasi karena keadaan cuaca cukup baik dan gelombang relatif jarang terjadi (Akbar et al. 2016). Menurut Setiawan et al. (2016) menyatakan bahwa musim penangkapan merupakan salah satu penentu nilai produksi di suatu perairan. 
Laju tangkap tertinggi terhadap hasil tangkapan pukat pantai yaitu ikan pepetek yaitu sebesar 0,8 kg/jam. Sedangkan target utama yang diharapkan tertangkap oleh pukat pantai memiliki laju tangkap sebesar 0,7 kg/jam. Secara keseluruhan laju tangkap untuk hasil tangkapan sampingan sebesar 2,72 kg/jam dan discard sebesar 0,62 kg/jam (Tabel 2). Hal ini menunjukkan bahwa perikanan pukat pantai memiliki nilai catch rate hasil tangkapan sampingan yang lebih besar dibandingkan nilai catch rate target tangkapannya. Dengan demikian perlunya pengelolaan dalam mengatur unit penangkapan ini agar sumberdaya ikan dapat seimbang dan berkelanjutan.

Tabel 2 Nilai laju tangkap (catch rate) pada pukat pantai

\begin{tabular}{lccc}
\hline \multirow{2}{*}{ Alat tangkap } & \multicolumn{3}{c}{ Nilai catch rate $(\mathrm{cr})$} \\
\cline { 2 - 4 } & Ikan target $(\mathrm{kg} / \mathrm{jam})$ & \multicolumn{2}{c}{ HTS $(\mathrm{kg} / \mathrm{jam})$} \\
\cline { 2 - 4 } & 0,70 & 2,72 & Discard \\
\hline Pukat pantai & \multicolumn{2}{c}{0,62} \\
\hline
\end{tabular}

Sumber: Data hasil pengukuran, data diolah (2017)

\section{KESIMPULAN DAN SARAN}

Nilai laju tangkap keseluruhan dari pengoperasian pukat pantai sebesar $24,25 \mathrm{~kg} / \mathrm{hari}$. Besarnya laju tangkap pukat pantai dengan hasil tangkapan ikan teri memiliki nilai sebesar $0,7 \mathrm{~kg} / \mathrm{jam}$. Sedangkan laju tangkap hasil tangkapan sampingan dan discard sebesar 2,72 kg/jam dan 0,62 kg/jam. Perikanan pukat pantai memiliki nilai catch rate hasil tangkapan sampingan yang lebih besar dibandingkan nilai catch rate target tangkapannya.

\section{DAFTAR PUSTAKA}

Akbar MA, Suryanto, Triharyuni S. 2016. Analisis perikanan huhate di Perairan Larantuka, Flores. Jurnal Penelitian Perikanan Indonesia. 22(2):115-122.

Apriliani I M, Dewanti LP, Zidni I. (2017). Karakteristik dimensi utama kapal perikanan pukat pantai (beach seine) di Pangandaran. Jurnal Airaha. 6 (2):48-53.

Blaber JM. 1997. Fish and fisheries of tropical estuaries. New York (US) : Chapman and Hall.

Boesono H, Anggoro S, Bambang AN. 2011. Laju tangkap dan analisis usaha penangkapan Lobster (Panulirus sp) dengan jaring lobster (gillnet monofilament) di Perairan Kabupaten Kebumen. Saintek Perikanan: Indonesian Journal of Fisheries Science and Technology. 7(1):77-87.

Firdaus, M. 2010. Hasil tangkapan dan laju tangkap unit perikanan pukat tarik, tugu, dan kelong. Makara Teknologi. 14(1):22-28.

Jumsurizal, Nelwan A, Kurnia M. 2014. Produktivitas penangkapan ikan tenggiri (Scomberomorus commerson) menggunakan pancing ulur di Perairan Kabupaten Bintan. Jurnal IPTEKS Pemanfaatan Sumberdaya Perikanan. 1(2):165-173.

Nurhayati A. 2013. Analisis potensi lestari perikanan tangkap di kawasan Pangandaran. Jurnal Akuatika. (4)2:195-209.

Setiawan U, Wenno J, Kayadoe ME. 2016. Laju tangkap dan musim penangkapan madidihang (Thunnus albacares) dengan tuna hand line yang didaratkan di Pelabuhan Perikanan Samudera Bitung. Jurnal Ilmu dan Teknologi Perikanan Tangkap. 2(4):147-154.

Sparre P, Venema SC. 1999. Introduksi Pengkajian Stok Ikan Tropis. Pusat Penelitian dan Pengembangan Perikanan, Badan Penelitian dan Pengembangan Pertanian. Jakarta (ID) : FAO. 
Sumiono B, Sudjianto, Soselisa Y, Murtoyo TS. 2002. Laju tangkap dan komposisi jenis ikan demersal dan udang yang tertangkap trawl pada musim timur di Perairan Utara Jawa Tengah. Jurnal Penelitian Perikanan Indonesia. 8(4):15-21.

Triharyuni S, Wijopriyono, Prasetyo AP, Puspasari R. 2012. Model produksi dan laju tangkap kapal bouke ami yang berbasis di PPN Kejawanan, Cirebon Jawa Barat. Jurnal Penelitian Perikanan Indonesia. 18(3):135-143. 